CSÁKI GYöRGY ${ }^{1}$

\title{
Az Átfogó Regionális Gazdasági Partnerség (RCEP) És INDIA Regional Comprehensive Economic PARTNership (RCEP) AND INDia
}

1989-ben Simai Mihály hívására lettem a Világgazdasági Kutatóintézet munkatársa. Az 1975-76-os tanévben ismertem meg őt, amikor a Világgazdaságtan címü tantárgy keretében a világgazdaság átfogó problémáiról, a multilaterális világgazdasági rend jellemzőiről adott elö. Az azóta eltelt 45 évben Simai professzor kitartóan és következetesen elemezte a multilateralizmus kérdéseit, rámutatva a problémákra, a megoldatlanságokra, a megoldások korlátaira. Ugyanakkor Simai Mihály mindig meggyöződéssel vallotta, hogy a multilaterális megoldások minden résztvevö számára hasznosak. Különös figyelemmel követtem, amit Simai professzor a globális kormányzás szükségszerüségéről írt sokszor idézve és folyamatosan tanítva koncepcióját. Gyakran rácsodálkoztam, milyen éles szemmel veszi észre - és mindig az elsők között! - a világgazdaság legfontosabb, leginkább meghatározó új jelenségeit. Kérdés, vajon a megaregionális szabadkereskedelmi tárgyalásokat/megállapodásokat a multilateralizmus bukásaként vagy annak új formájaként értékeli-e? De nagyon remélem, hogy osztja véleményemet a kérdés meghatározó jelentőségéről „Korunk világgazdaságában”.

In 1989 I was invited by Mihály Simai to join the Research Institute of World Economy. I acquainted him in the year 1975-76, when I attended his World Economics lectures on comprehensive problems of the word economy, and particularities of the multilatral world order. In the past 45 years Professor Simai persistently and consistently analysed the matter of multilateralism, highlighting its problems, incompleteness and limits. However Mihály Simai has kept strong convinction that multilateral solutions are beneficial for all parties involved. I followed, cited and taught with particular devotion what Professor Simai had been writing about the necessity of global governance. I admired his ability to identify always among the firsts - the most important and defining new phenomenons in the world economy. I wonder he evaluates megaregional free trade negotiations and agreements as failure of multilateralism or its new kinds instead. Either way, I strongly hope that he shares my view about the importance of this question in the 'World economy of our times'.

\footnotetext{
${ }^{1}$ egyetemi tanár (Szent István Egyetem Közgazdaságtudomány, Jogi és Módszertani Intézet)
} DOI: 10.14267/RETP2020.01.16 
Az előttünk álló évtized minden bizonnyal legsúlyosabb világgazdasági kockázatát a világkereskedelem perspektíváinak kiszámithatatlansága jelenti. A világkereskedelem bővülésének 2012-13 óta tartó, a korábbi évtizedek dinamikájától jóval lassúbb bővülése önmagában is növekedéskorlátozó tényező, de sokkal nagyobb veszélyeket rejt magában a multilaterális kereskedelemszabályozás összeomlása és a kiszámithatatlanul erösödő protekcionizmus.

A WTO már korábban is működésképtelenné vált. (A 2006 óta a mai napig „felfüggesztett” Doha-forduló, a sokoldalú kereskedelmi megállapodások létrehozására való teljes képtelenség, ${ }^{2}$ a szolgáltatáskereskedelem 1995 óta tervezett szabályozásának teljes sikertelensége stb. a jelei ennek a működésképtelenségnek.) A WTO egyetlen működő intézménye s így egyetlen valóban hasznos tevékenysége a vitarendezés volt: 1995. január 1. és 2020. január 20. között 593 tagállamok közötti kereskedelmi vita került a Vitarendezési Testület elé, s több mint 350 határozat született meg. ${ }^{3}$ 2019. december 19. óta azonban a Vitarendezési Testület is működésképtelenné vált, miután nem sikerül új tagokat jelölni (nemhogy megválasztani!) a Vitarendezési Testület Fellebbviteli Testületébe („Appellate Body”) az USA vétói következtében. Így bizonytalan ideig a konzultációs szakaszban lezárható vitákon túl nem születhet vitarendezési döntés: nincs hova fellebbezni az elsőfokú döntés után!

2012-13-ban úgy tünt, hogy az ún. megaregionális szabadkereskedelmi tárgyalások/megállapodások lendíthetik elöre a nemzetközi kereskedelem problémás ügyeit. A WTO adatbázisa szerint $^{4} 2020$ januárjában 303 regionális szabadkereskedelmi megállapodás ( $R T A=$ Regional Trade Agreement) van hatályban, melyek közül 149 áruk kereskedelmére, míg 2 szolgáltatáskereskedelemre vonatkozik, a többi 152 megállapodás hatálya az áruk és a szolgáltatások kereskedelmére egyaránt kiterjed. Ami az RTS-k földrajzi megoszlását illeti: ${ }^{5}$ az Európai Unió 42 RTA részese, Kína 15, Ausztrália és az Amerikai Egyesült Államok pedig 14-14 regionális szabadkereskedelmi megállapodás részese.

Megaregionális az a szabadkereskedelmi tárgyalás/megállapodás, melynek legalább az egyik oldalán több ország áll. A mindennapi szóhasználatban azonban csak azokat a szabadkereskedelmi megállapodásokat nevezzük megaregionálisnak, ahol mindkét fél világgazdaságilag jelentős szereplö. ${ }^{6}$

\footnotetext{
${ }^{2}$ Az egyetlen, s nem alapvető fontosságú, alapvetően technikai jellegű megállapodás, amelyet 2017-ben ratifikáltak a tagállamok a „Trade Facilitation Agreement”. Ez az egyetlen sokoldalú megállapodás, amelyet a tagállamok minősített többsége 25 év alatt elfogadott.

${ }^{3}$ https://www.wto.org/english/tratop_e/dispu_e/dispu_e.htm

${ }^{4}$ http://rtais.wto.org/UI/publicsummarytable.aspx

${ }^{5}$ http://rtais.wto.org/UI/publicPreDefRepByCountry.aspx

${ }^{6}$ Ezért nem tekintjük megaregionális szabadkereskedelmi egyezménynek az EU 42 regionális megállapodását, ugyanakkor az EU - Kanada és föként az EU - Japán megállapodások megaregionálisnak tekinthetők.
} 
Három megaregionális szabadkereskedelmi tárgyalássorozat vonzott különleges figyelmet a 2010-es évek elejétől: a TTIP, a TPP és az RCEP. ${ }^{7}$

A legkiterjedtebb megaregionális szabadkereskedelmi tárgyalás az EU és az USA között 2013-ban megkezdett Transzatlanti Kereskedelmi és Beruházási Partnerségi megállapodás (TTIP) volt, ez azonban 2016 decemberében csöndben kimúlt. ${ }^{8}$ A TTIP-tárgyalások hét nagy témakört öleltek fel: áruk kereskedelme, szolgáltatáskereskedelem, beruházások, gazdasági és technikai együttműködés, szellemi tulajdon, versenyszabályozás és vitarendezés. Az EU és az USA közti kereskedelmi forgalom a világ legnagyobb „kétoldalú” forgalma: 2018-ban az EU 28 tagállamából az USA-ba irányuló export meghaladta a 406 milliárd eurót, ezzel szemben 268,8 milliárd euró értékű import érkezett Európába csaknem 178 milliárd eurós kereskedelmi többletet eredményezve. ${ }^{9}$ Folyamatosak ugyanakkor a kereskedelmi viták: a WTO-ban a két legnagyobb panasztevő és a két legnagyobb bepanaszolt ugyanazok az országok, és ráadásul panaszaik túlnyomó részét egymás ellen tették/teszik. A TTIP legfontosabb elemét a nem vámjellegü korlátozások enyhítése jelentette: a vámok már jó ideje kölcsönösen meglehetősen alacsonyak, a műszaki szabályozások, sztenderdek és más eljárások összehangolása vagy/és harmonizálása azonban komoly kereskedelmi akadályokat szüntethetne meg az áruk és a szolgáltatások kereskedelmében egyaránt. Régi amerikai követelést próbáltak meg kezelni a beruházások hazai beszállítói tartalmáról és az európai uniós közbeszerzések helyi szállítókra vonatkozó preferenciáinak enyhítéséről kezdett tárgyalások. A tárgyalásokat a kezdetektől nagy gyanakvás és bizonytalanság fogadta az óceán mindkét partján: sokan kárhoztatták a tárgyalások „titkosságát” (amire reakcióként az Európai Bizottság minden korábbinál több konkrét információt tett közzé a tárgyalásokról). ${ }^{10}$ Számos ismert társadalomtudós és sok civil szervezet környezeti és fenntarthatósági problémákra hivatkozva bírálta az egész tárgyalási folyamatot. Így a TTIP diszkrét elhalása nem kelt különösebb hiányérzetet az Atlanti-óceán egyik partján sem.

A TTIP csendes-óceáni „párja”, a Csendes-óceáni Partnerség (Trans-Pacific Partnership, TPP) az ázsiai - csendes-óceáni térség kereskedelmi kapcsolatainak bővítésére irányul. A tárgyalásokon 12 ország vett részt: Ausztrália, Brunei, Chile, az Egyesült Államok, Japán, Kanada, Malajzia,

\footnotetext{
${ }^{7}$ Azokat a kereskedelempolitikai tárgyalásokat, melyek több mint bilaterálisak (kétoldalúak), de nem multilaterálisak (sokoldalúak: olyan kereskedelempolitikai tárgyalások, melyeken a WTO valamennyi tagországa részt vesz) szokás a plurilaterális (többoldalú) névvel is illetni. Ennek tipikus példája a Trade in Services Agreement (TiSA), melyet a WTO 23 tagja folytat Ausztrália kezdeményezésére. Amennyiben megszületik az egyezmény, az kimozdítaná a holtpontról az 1995 óta érdemi tevékenységet nem folytató GATS-ot. A TiSA különleges jelentősége abban rejlik, hogy ahhoz minden WTO tagország csatlakozhat - önkéntesen, mert nem multilaterális megállapodás (lenne), így kikerülné a WTO döntéshozatalának legfontosabb akadályát, a konszenzus kötelezettségét. Voltaképpen a megaregionális szabadkereskedelmi tárgyalások/megállapodások a plurilaterális tárgyalások/megállapodások egy csoportját képviselik.

${ }^{8}$ A TTIP tárgyalások 2016 decemberében „megállapodás nélkül véget értek”, miután az Európai Tanács 2019. április 15-én megállapította: „A TTIP direktívák idejétmúltak és többé nem relevánsak” (https:// ec.europa.eu/trade/policy/in-focus/ttip/). Az csak igen felületes - politikailag erősen motivált - látszat, hogy Trump elnök lépett vissza a TTIP-től - másfél hónappal a tárgyalások eredménytelen lezárása után indított PR-akciót a TTIP ellen.

${ }^{9}$ Eurostat: https://appsso.eurostat.ec.europa.eu/nui/show.do?dataset=ext_lt_mainez\&lang=en

${ }^{10}$ Lásd: http://ec.europa.eu/trade/policy/in-focus/ttip/
} 
Mexikó, Peru, Szingapúr, Új-Zéland és Vietnam. A TPP célja a kereskedelmi forgalom és a beruházási tevékenység bővítése a partnerek között, az innováció és a gazdasági növekedés élénkítése, a munkahelyteremtés és -megtartás elősegítése. A tárgyalások zárt ajtók mögött folytak, ez szolgáltatta a fó okot a civilszervezetek kritikájára: számukra átláthatatlanok és ellenőrizhetetlenek voltak. A TTP-megállapodást 2015. október 5-én aláirták. Az egyezmény ratifikálására nem került sor, s 2017 januárjában - ugyancsak első munkanapján! - Trump elnök visszavonta az USA aláirását. A szerződésben maradt 11 ország (amelyek a világ GDP-jének 13,5 százalékát állítják elö) 14 hónap elteltével megújította s némileg átalakította az eredeti egyezményt, amit 2018. március 8-án Comprehensive and Progressive Agreement for Trans-Pacific Partnership (CPTPP) néven írtak alá Santiago de Chilében. Ma ez a legnagyobb szabadkereskedelmi egyezmény a világon! ${ }^{11} \mathrm{~A}$ hatályba lépésre a 6 ország ratifikálását követő 60 . naptári napon kerül sor.

Komoly fordulatot jelentett a TPP-tárgyalások során, hogy 2013-ban Japán is bekapcsolódott. Ennek oka, hogy Abe Sinzo miniszterelnök megpróbált életet lehelni az 1990 óta stagnáló japán gazdaságba, és liberalizálásában kulcsszerepe lehet a TPP-nek [Koike, 2015]. Az USA a TPPvel elérni látszott valamennyi fontos kereskedelempolitikai célját a csendes-óceáni térségben: az agrárprotekcionizmus jelentős csökkentését, a szellemi tulajdon fokozott védelmét és néhány feldolgozóipari ágazatban (például a jármügyártásban) alkalmazott korlátozások enyhítését. Erre mondták: „az USA kis csalival nagy halat fogott” [Hamada, 2015]. Természetesen az USA-nak a szellemi tulajdonjogokkal kapcsolatos, a szabadalmak és a szerzői jogok megerösítését célzó javaslatai körül komoly ellentétek voltak. Vitatták a befektetők és az államok közötti vitarendezés mikéntjét is. A bírálók szerint a hagyományos beruházási egyezmények általában összeegyeztethetetlenek a környezetvédelmi és emberijog-védelmi szempontokkal csakúgy, mint az államok jóléti szabályozásával, ezért félö, hogy a TPP gyöngíteni fogja az aláíró államokban a környezetvédelmi, munkavédelmi és kártérítési szabályokat. A szakszervezetek, például az AFL-CIO (a legjelentősebb USA-beli szakszervezeti szövetség) aggódnak, hogy a nagy vállalatbirodalmak szándékai háttérbe szorítják az összes többi érdeket, beleértve az alkalmazottakéit is.

Az USA kilépése után a helyzet nagyon bizonytalanná vált, nem volt világos, hogy a szerződésben maradt 11 ország az USA nélkül is akarja-e a megállapodást, s ha igen, milyen változtatásokkal? 2017 novemberében azután Vietnamban a 11 ország miniszteri értekezletén megerösítették a módosított TPP-hez kapcsolódó elkötelezettségüket - s négy hónap alatt megszületett a CPTPP. A CPTPP nagyrészt érintetlenül tartalmazza a TPP eredeti szövegét, a szerződés ${ }^{12} 30$ fejezetéből 20 változatlan maradt, összesen 22 rendelkezés változott meg vagy került ki a szerződésből [Goodman, 2018]. A változások elsősorban azokat a rendelkezéseket érintették, amelyek különösen fontosak voltak az USA számára, amelyeknek a szerződésbe foglalását az USA szorgalmazta. A legfontosabb változtatások a beruházások szabályozásával és a szellemi tulajdon védelmével foglalkozó fejezetekben találhatók. A CPTPP beruházási fejezete szerint például sokkal korlátozottabb

\footnotetext{
${ }^{11}$ A TPP a világ összes GDP-jének 37,4, a globális kereskedelmi forgalomnak pedig 25,9 százalékát képviselte volna. A CPTPP részesedése ennél szerényebb: a világ GDP-jének 14, a globális világkereskedelmének 15 százalékát reprezentálja [Helble - Xue, 2017].

${ }^{12}$ A CPTPP szövege megtalálható csaknem valamennyi részes ország kormányzati honlapján. Lásd például a kanadai kormány honlapját: http://international.gc.ca/trade-commerce/trade-agreements-accordscommerciaux/agr-acc/cptpp-ptpgp/text-texte/cptpp-ptpgp.aspx?lang=eng Lekérdezve: 2018. 03.16.
} 
lesz a befektetők azon képessége, hogy a befektetési megállapodások és a befektetési engedélyek alapján folytassák le az esetleges vitarendezést. Lerövidül az innovatív gyógyszerek szabadalmi védettségének ideje, leszűkült a technológia és az információ védelme, az írott szövegek szerzői jogvédelmének ideje is rövidebb lett, mint ahogyan a TPP rendelkezett. „Ezen rendelkezések felfüggesztése ellenére a CPTPP szellemi tulajdon védelmére vonatkozó fejezete a legfejlettebb és legrészletesebb szellemi tulajdonjog-védelmi sztenderdeket jelentik bármely napjainkig megkötött kereskedelmi egyezményben. Jelentős védelmet nyújt a külföldön tevékenykedő vállalatok számára innovációik ellopása ellen." (Goodman, 2018. - kiemelés tőlem: Cs. Gy.) Nem változtak az állami vállalatokra, az e-kereskedelemre és a közbeszerzésre vonatkozó rendelkezések. Ezek az elemek nemcsak a CPTPP 11 országa számára, hanem a globális kereskedelmi rendszer szempontjából is pozitív fejleményt jelentenek, és erősen összhangban állnak az USA érdekeivel is.

\section{Átfogó Regionális Gazdasági Partnerség}

Az ASEAN tagországai (Brunei, Fülöp-szigetek, Indonézia, Kambodzsa, Laosz, Malajzia, Mianmar, Szingapúr, Thaiföld és Vietnam), valamint a vele szabadkereskedelmi megállapodással rendelkező hat állam (Ausztrália, Dél-Korea, India, Japán, Kína és Új-Zéland) között folyik az Átfogó Regionális Gazdasági Partnerség (Regional Comprehensive Economic Partnership, RCEP) tárgyalássorozata. A tárgyalássorozat 2012 novemberében kezdődött, $s$ alapját az ASEAN dinamikusan bővülő külkereskedelmi forgalma tette szükségessé: 1999 és 2009 között az ASEAN Kínába irányuló exportja 6,9-szeresére, onnan származó importja pedig 5,8-szorosára nőtt. Ugyanezen időszakban az ASEAN-ból Indiába irányuló export a 4,5-szeresére, az ellenirányú forgalom 5,6-szorosára nött. Japán és Dél-Korea is igen dinamikusan növelte az ASEAN-nal bonyolított külkereskedelmi forgalmának volumenét, noha részesedésük az ASEAN külkereskedelmi forgalmából kis mértékben csökkent. Az ASEAN általában is igen aktív volt a regionális szabadkereskedelmi megállapodások létrehozásában [Fukunaga-Isono, 2013]

1. táblázat: Hatályban lévő szabadkereskedelmi megállapodások a 6 RCEP-partnerország között

\begin{tabular}{|c|c|c|c|c|c|c|}
\hline & ASEAN & Ausztrália & Kína & Japán & Új-Zéland & Dél-Korea \\
\hline ASEAN & - & Igen & Igen & Igen & Igen & Igen \\
\hline Ausztrália & Igen & - & Igen & Igen & Igen & Igen \\
\hline Kína & Igen & Igen & - & Nincs & Igen & Igen \\
\hline Japán & Igen & Igen & Nincs & - & Nincs & Nincs \\
\hline Új-Zéland & Igen & Igen & Igen & Nincs & - & Igen \\
\hline Dél-Korea & Igen & Igen & Igen & Nincs & Igen & - \\
\hline
\end{tabular}

Forrás: https://www.cnbc.com/2019/11/12/what-is-rcep-asia-pacific-trade-deal-slated-to-be-worldslargest-fta.html Downloaded: 05/01/2020

Az RCEP célja - a legelterjedtebb megfogalmazás szerint - voltaképpen az ASEAN hat szabadkereskedelmi megállapodásának egységes rendszerbe foglalása, az RCEP ezért a „legegyszerűbb” megaregionális megállapodásnak látszott. Az RCEP rendelkezik mind a hat partnerrel szabadkereskedelmi megállapodással - azok azonban nem feltétlenül rendelkeznek egymással is ilyen kétoldalú megállapodással (lásd 1. számú ábra). Az RCEP aláírása automatikusan létrehozná a Japán és Kína, Új-Zéland, valamint Dél-Korea közötti szabadkereskedelmi megállapodásokat. 
Az RCEP(16)-országok 2018-ban a világexport 26, míg a világimport 27 százalékát realizálták, India nélkül - RCEP15 - ezek az arányok 24,8 és 25,2 százalékra csökkennek (lásd 2. táblázat).

Az RCEP-tárgyalások napirendjére hét konkrét kérdést vettek fel: áruk kereskedelme, szolgáltatáskereskedelem, beruházások, gazdasági és technikai együttmüködés, szellemi tulajdon, versenyszabályozás és vitarendezés. A napirend nyitott, a tárgyalások során egyéb kérdések is felmerülhetnek. ${ }^{13}$ A tárgyalássorozatot 2012-ben hirdették meg és a megbeszélések 2013-ban kezdődtek meg.

Az RCEP-tárgyalások a TPP-tárgyalásokkal párhuzamosan indultak, s az elemzők a kezdetektől bizonyos rivalizálást láttak a két elérni remélt szabadkereskedelmi megállapodás között. ${ }^{14}$ Ennek egyik természetes oka az volt, hogy Kína az RCEP-et egy későbbi Csendes-óceáni Szabadkereskedelmi Övezet felé vezető alternatív útnak tartotta, s végig kezdeményező szerepet töltött be a tárgyalásokon [Gantz, 2016].

A tárgyaló felek az alábbi célok elérését remélték a tárgyalások megkezdésekor:

- a vámok 95 százalékának felszámolása,

- egy közös piac eléréséhez vezető menetrend elfogadása,

- a szellemi tulajdonjog, a beruházások, a környezetvédelem, a pénzügyi szolgáltatások és a munkajogi elöírások szabályozásának összehangolása,

- a hazai szerkezeti reformok támogatása,

- az utak, kikötők, erőmüvek és egyéb infrastrukturális létesítmények fejlesztése,

- kereskedelem-könnyítés - különös tekintettel a vámigazgatási szolgáltatások javítására.

A TPP- és az RCEP-tárgyalások megkezdésekor kiemelten fontos volt a tárgyaló felek Kínához való viszonya és viszont, Kína választása (ha egyáltalán választani kívánt) a TPP és az ARCEP között). Miután 2013-ban a kínai kereskedelmi miniszter kijelentette, hogy „Kína komolyan tanulmányozza a TPP-t”, az USA-ban egyre-másra optimista nyilatkozatok hangzottak el: „a TPP nem áll ellentmondásban Kína felvilágosult nemzeti érdekeivel”, „az USA vezette TPP jól összeegyeztethető a nyitottabb és barátságosabb Kínával”, „Kína csatlakozása a TPP-hez azonnal a jó hírnévhez kötődő előnyöket eredményezne Kínának és a fokozott gazdasági teljesítmény magvait vetné el” stb. Annál is inkább, mert Kína felismerte, hogy a megaregionális szabadkereskedelmi tárgyalások a jövő kereskedelmi szabályait dolgozhatják ki és - az USA-hoz - hasonlóan meglehetősen frusztrálttá vált a WTO működésképtelensége miatt.” [Ye, 2015] Miután azonban az USA egyre gyakrabban hangsúlyozta, hogy a TPP egyik célja, hogy ne Kína írja a jövendő kereskedelmi szabályait, hanem értelemszerüen az USA, vagy egy országcsoport az USA irányításával, ${ }^{15}$ illetve Japán is csatlakozott a TPP-hez, Kína diplomatikusan a háttérbe húzódott ${ }^{16}$ és figyelmét az RCEP felé fordította. [Ye, 2015]

\footnotetext{
${ }^{13}$ Az RCEP-re vonatkozó általános információk megtalálhatóak az ASEAN honlapján: https://asean.org/?static_post=rcep-regional-comprehensive-economic-partnership.

${ }^{14}$ Ausztrália, Uj-Zéland és Japán, valamint Brunei, Malajzia, Szingapúr és Vietnam (az ASEAN tagjai) mindkét megállapodás részesei.

${ }^{15}$ Az USA-ban valószínűleg erősen túlbecsülték a TPP globális stratégiai jelentőségét, elsősorban Kína „visszaszorításának” reményét. [Aggarwal, 2016]

${ }^{16}$ Hivatalosan Kína sohasem csatlakozott a TPP tárgyalásokhoz.
} 
2. táblázat: Az RCEP-országok külkereskedelmi forgalma, 2018, millió USA dollár

\begin{tabular}{|c|c|c|}
\hline & Export & Import \\
\hline Brunei & 7052 & 5680 \\
\hline Kambodzsa & 18414 & 21420 \\
\hline Indonézia & 208657 & 216197 \\
\hline Laosz & 6060 & 7262 \\
\hline Malajzia, & 245588 & 218498 \\
\hline Mianmar & 17109 & 19586 \\
\hline Fülöp-szigetek & 88020 & 127686 \\
\hline Szingapúr & 634842 & 540210 \\
\hline Thaiföld & 331762 & 274868 \\
\hline Vietnám & 259829 & 251368 \\
\hline ASEAN: & 1479511 & 1682775 \\
\hline Kína & 2684284 & 2547312 \\
\hline India & 537248 & 696174 \\
\hline Ausztrália & 327148 & 308811 \\
\hline Új-Zéland & 56691 & 57055 \\
\hline Japán & 927612 & 924803 \\
\hline Dél-Korea & 722038 & 637833 \\
\hline Világ összesen & 24971375 & 24440775 \\
\hline RCEP16 & 6734532 & 6854763 \\
\hline RCEP15 & 6197284 & 6158589 \\
\hline RCEP16/Világ & 26,96900751 & 28,04642242 \\
\hline RCEP15/Világ & 24,8175521 & 25,19801029 \\
\hline
\end{tabular}

Forrás: https://unctadstat.unctad.org/wds/TableViewer/tableView.aspx Lekérdezve: 2020. 02.01.

Japán számára mind a CP-TPP, mind pedig az RCEP a gazdaságpolitika általános liberalizációja („az „abenomics”) részeként fontos, a japán kormány komoly áldozatokra is hajlandó az átfogó kereskedelemliberalizáció érdekében. A TPP-ben és az RCEP-ben egyaránt az agrárvámok jelentős csökkentése van napirenden, ami a hagyományos japán protekcionizmus egyik legfontosabb elemét rendíti meg. Az Abe-kormány azonban az ipari és szolgáltatásexport növelésének oltárán hajlandó feláldozni a mezőgazdasági termelés egy részét is: a CP-TPP a japán rizstermelés 13 százalékos csökkenését eredményezi s az RCEP is hasonló hatásokkal jár [Lee - Itakura, 2014].

Az RCEP-t kevésbé nagyravágyó célkitüzései látszólag könnyebben megvalósíthatóvá teszik, mint a TPP-t, illetve a CP-TPP-t: az RCEP csak hat nem vámjellegű korlátozás enyhítését/megszűntetését tűzte ki célul, szemben a CP-TPP 20 hasonló konkrét korlátozásával [Wilson, 2015]. 
Az RCEP fontos célja a „tésztás tál” vagy „spagettis tál”17 hatás felszámolása: az egyre nagyobb számú szabadkereskedelmi megállapodás bonyolult és egymástól eltérő szabályai riasztók a vállalatok (különösen a kis- és közepes vállalatok) számára, ezért igen gyakran nem is veszik igénybe az egyes szabadkereskedelmi egyezmények által nyújtott - elvben kedvezményes - lehetőségeket [Wilson, 2015].

Az RCEP-ben is kiemelt fontosságú a szellemi tulajdonjogok kérdése - ha nem is övezték olyan heves viták, mint a TPP-tárgyalások során. A CP-TPP 20 ponton enyhítette az eredetileg az USA által követelt elöírásokat, de ezek között a legkiterjedtebb megállapodás a szellemi tulajdonjogok kereskedelmi vonatkozásairól szól. Az RCEP-megállapodás szövegtervezeteit nem hivatalosan hozták nyilvánosságra, az elemzők egy „megbízhatónak látszó” kiszivárogtatott változatból dolgoznak. Ennek alapján az a meglepő megállapítás fogalmazható meg, hogy „a végső megállapodás aligha jelent alternatívát (a CP-TT-hez képest - Cs. Gy.), amit számos politikus, elemző és civil szervezet remélt. Valóban, az elemzők csalódottan fedezték fel az RCEP előzetes anyagában és a TPP-megállapodásban szereplő szellemi tulajdonjogra vonatkozó fejezetek erős hasonlóságát" [Yu, 2017:700]. Ez nem meglepő, ha figyelembe vesszük az RCEP-ben részes fejlett országok erőteljes elkötelezettségét a szellemi tulajdonjogok védelmére. Dél-Korea számára pedig az USA-val 2012-ben életbe lépett szabadkereskedelmi megállapodás vonatkozó elöŕrásai a mérvadók az RCEP-ben is. Az RCEP-megállapodásnak a szellemi tulajdonjogokkal kapcsolatos fejezete öt témát ölel fel: szerzői jog, védjegyek, szabadalmak, az üzleti titok és a szellemi tulajdonjogok érvényesitése [Yu, 2017:706-716]. Legnagyobb valószínüséggel a CP-TPP vonatkozó elöírásaihoz hasonló szabályozás kerül az RCEP végső változatába - Kína (és a tárgyalást otthagyó India) az eredeti japán - dél-koreai igényeknél jóval enyhébb szabályokat hajlandó elfogadni. ${ }^{18}$

A TPP és az RCEP egyaránt módosíthatja a globális világgazdasági erőviszonyokat. Mivel a TPP-ből kilépett az USA, így a Kína globális és regionális (azaz: ázsiai) előretörésének legalábbis korlátozása a CP-TPP-ben nyilvánvalóan nem értelmezhető. Az RCEP-ben ugyanakkor India kilépése következtében ugyancsak nem képződik ellenerő a folyamatosan erősödő kínai kereskedelmi fölénnyel szemben. Következésképpen a „csonka” megaregionális egyezmények pozitív hatásai jóval kisebbek lesznek a tárgyalások megkezdésekor feltételezettnél, reméltnél.

Érdekes kérdés ugyanakkor a CP-TPP és az RCEP viszonya a multilateralizmushoz. Egyrészt a megaregionális szabadkereskedelmi tárgyalások alapvetően a multilaterális kereskedelmi tárgyalások - azaz a WTO - kudarcának termékei. Másrészt mivel túlmutatnak a kétoldalú megállapodásokon, s legalább regionális jellegüek vagy éppen két régió közöttiek, ezért a multilateralizmus megnyilvánulásaként is értelmezhetők [Wilson, 2015].

\footnotetext{
${ }^{17}$ Mind a sajtóban, mind pedig a szakirodalomban igen elterjedt kifejezés, amely minden valószínűség szerint Jagdish Bhagwatitól származik: mint egy halom tészta a tálban, az egész átláthatatlan és az egyes alkotóelemek nem azonosíthatók.

${ }^{18}$ Az amerikai elemzők ezt nevezik - kellő iróniával - „TPP-lite” változatnak.
} 


\section{INDIA KILÉPÉSE AZ RCEP-BöL}

India az ASEAN Bankokban 2019. október 31. és november 4. között tartott 35. csúcstalálkozóján - nem teljesen váratlanul ${ }^{19}$ - bejelentette, hogy kilép az RCEP-tárgyalásokból.

Az indiai delegáció és maga Modi miniszterelnök a döntést a megállapodásnak a piacra jutással, az eredet-megjelölési szabályokkal, a vámengedményekkel és a nem vámjellegü korlátozásokkal kapcsolatos elóírásaira vonatkozó, a tárgyalássorozat folyamán mindig hangoztatott indiai fenntartásokkal magyarázta [Cyrill, 2019]. Noha India 2020 végéig visszatérhet(ne) a tárgyalóasztalhoz és részese lehet(ne) egy esetleges RCEP-megállapodásnak, de ennek esélye igen csekély.

India már rendelkezik kétoldalú szabadkereskedelmi egyezménnyel az ASEAN-nal, valamint Japánnal, Malajziával, Szingapúrral, Thaifölddel és Dél-Koreával - vagyis a 15 RCEP-partner közül 12-vel. Az RCEP így India számára - a meglévő szabadkereskedelmi megállapodások egységes szerkezetbe foglalásán túl - három új szabadkereskedelmi megállapodást jelentene: Kínával, Ausztráliával és Új-Zélanddal szemben kellene jelentős mértékben csökkenteni a vámokat. És éppen ebben a három relációban érzékeli a Modi-kormány a legnagyobb veszélyeket.

India 2018-ban 105 milliárd dollár kereskedelmimérleg-hiánnyal rendelkezett a többi 15 RCEP-országgal szemben, ebből 54 milliárd dollárnyi volt a Kínával szembeni kereskedelmi mérleghiány [Oba, 2019]. Indiában erős félelmek élnek - a kormánypártok és az ellenzék oldalán egyaránt - a további kínai árubeáramlástól. Attól tartanak, hogy a szabadkereskedelem révén növekvő feldolgozóipari import súlyos csapást jelentene az indiai iparra. India - eredeti tárgyalási ajánlata szerint - kész volt az ASEAN országokból származó import 65 százalékára vámkedvezményeket nyújtani, amit 10 év alatt további 15 százalékkal lett volna kész bővíteni. Japán és Dél-Korea számára - melyekkel India már korábban szabadkereskedelmi megállapodást kötött a termékek 62,5 százalékára ajánlott vámkedvezményeket. A többi RCEP részes ország irányába - elsősorban tehát Kínának - India eredetileg az áruk 42,5 százalékára biztosított volna vámkedvezményeket. A többi tárgyaló fél erőteljes ellenkezésének hatására India 2017 végén jelentős engedményeket tett (korábbi álláspontjához képest): hajlandó volt vámkedvezményt adni a Kínából, Ausztráliából és Új-Zélandból származó áruimport 74 százalékára, valamint a többi részes országból származó import 86 százalékára. A többi tárgyalófél azonban az indiai áruimport 92 százalékára követelt vámkedvezményeket a többi 15 részes ország számára egységesen [Pant - Sarma, 2019]. India az egyike a legmagasabb vámtételeket alkalmazó RCEP-országnak, így India számára jelentené a legnagyobb vámcsökkentést a nulla vámok rendszere.

India vonakodva lépett be az RCEP-tárgyalásokba, de később egyre inkább elfogadta a mélyebb gazdasági integráció szükségességét elsősorban annak érdekében, hogy javítsa az indiai vállalatok pozícióit a globális értékláncokban [Cyrill, 2019]. Az RCEP Indián belüli ellenzői a szabadkereskedelmi megállapodástól féltik az ország mezőgazdasági termelőit, a tejipart, a feldolgozóipart (ebben elsősorban a textilipart, a gyógyszeripart, a vegyipart és az acélgyártást). A feldolgozóipart, s azon belül is elsősorban a kisvállalkozásokat föleg a kínai import növekedé-

\footnotetext{
${ }^{19}$ A 2015-ös csúcstalálkozót elsősorban annak kellett szentelni, hogy meggyőzzék Indiát arról, hogy engedjen a szolgáltatások piacra jutásának kérdésében - hiszen azon a területen maga is erős exportoffenzívára törekszik, s az akkori kormányprogram szerint India részesedését a világexportban (2015-ről 2020-ra) 2 százalékról 3,5 százalékra akarta növelni. [Gantz, 2016]
} 
sétől féltik, a tejiparban Ausztrália konkurenciáját érzik kivédhetetlennek egy átfogó szabadkereskedelmi megállapodás részeseként. (Indiában 70 millió háztartás megélhetése függ közvetlenül vagy közvetve a tejtermeléstől.) Egy RCEP kiterjedésủ szabadkereskedelmi megállapodás veszélyt jelenthet a kormány által meghirdetett „Made in India” programra is. A kormány ezek mellett kereskedelemtechnikai aggályokat is megfogalmazott, elsősorban az eredetmegjelölési szabályok és a vámérték-számítás bázisévének kijelölése terén [Vijayakumar, 2019].

„Az igazi probléma az lehet, hogy India nem elég versenyképes. India nehéznek találja, hogy megfeleljen a globális versenytársak árainak és minőségének. Fontos korlátokat jelent az ország föld- és munkaerőpiacának merevségei. Ezt a versenyképtelenségi tényezőt kell Indiának sürgősen javítania - strukturális reformok révén." [Vijayakumar, 2019] Éppen ezért az RCEP-ből való kilépés - hosszabb távon - nem a megfelelő fejlődési út.

India egy év „gondolkodási idővel” rendelkezik, 2020 végéig visszatérhet a tárgyalóasztalhoz. Több szakértő és néhány kormány is reménykedik ebben. A legerőteljesebben a japán kormány sürgeti India visszatérését az RCEP-tárgyalásokba: „Japán egyáltalán nem gondolkodik India nélküli RCEP-ben”, illetve „Japán folytatja India meggyőzését arról, hogy csatlakozzon újra” nyilatkozta a METI államtitkára [Sim, 2019]. A japán miniszterelnök kabinetfönöke úgy fogalmazott: „Japán reméli, hogy továbbra is vezető szerepet játszhat 16 ország - beleértve Indiát - RCEP-megállapodásában” [Sim, 2019].

Kína nem csak exportoffenzívája révén veszélyezteti az indiai gazdaság pozícióit. (A Kínával szembeni kereskedelmi deficit 2018-ban az ország GDP-jének 2,2 százalékával volt egyenlő.) Kína - állítja Graham Allison, a Harvard Egyetem professzora - kihasználja India jogkövető magatartását, széleskörü dömpinget és egyéb nem tisztességes kereskedelmi gyakorlatot folytat, eközben teljes indiai ágazatokat szorít ki piacáról, beleértve India igen fejlett, 181 milliárd dolláros információtechnológiai iparát is. Kína tisztességtelen kereskedelmi gyakorlata szisztematikusan aláássa az indiai feldolgozóipart és az ország versenyképességét [Chellaney, 2019]. Ebből azonban nem következik egy protekcionista gazdaságpolitikai fordulat elkerülhetetlensége, de hasznossága sem. India, szemben az RCEP-országok többségével nem exportvezérelt gazdaság, hanem egy erősen importfüggő ország, melynek növekedését nagyrészt a belső fogyasztás húzza. Indiának saját erőből kell versenyképesebbé válnia, nincs olyan magas kereskedelmi korlát, amely megvédhetné az országot Kína kereskedelmi erejétől. Más kérdés, hogy India nem válhat versenyképesebbé, ha nem képes megfékezni a kínai dömpinget és a tisztességtelen kereskedelmi gyakorlatot [Chellaney, 2019].

Minden protekcionista intézkedéssel szemben felvetödik, Így az indiai tejtermelés és tejipar védelméről is elmondható (illetve arról, hogy az indiai politikai elit nem hajlandó jelentősen enyhíteni az ágazat védelmét), hogy a termelői lobbicsoportok erősebbnek bizonyultak, mint a fogyasztók érdekei. $\mathrm{S}$ az is igaz, hogy a kínai feldolgozóipar további piacokat nyerhetne Indiában a szabadkereskedelmi megállapodás révén, de ezzel szembeállítható, hogy - a viszonosság elve alapján - a szabadkereskedelmi egyezmény komoly elönyöket jelenthetne az indiai szoftver-és ICT-export számára.

Az India 1991-es nagy kereskedelmi reformja óta eltelt 28 évben az indiai gazdaság látványos növekedést - évi átlagosan 6-8\%! - produkált, ami össze sem hasonlítható az 1960-1970-es évek 1-3 százalékos növekedési teljesítményével. Ezzel egyidejűleg az abszolút szegénységben élők aránya 50 százalékról 20 százalékra csökkent [Mitra, 2019]. Leszögezhetjük tehát, hogy India az elmúlt harminc évben nem volt a kereskedelemliberalizáció vesztese!

India az elmúlt másfél évtizedben sajátos új pozíciókat foglalt el a világgazdaságban, s ez megváltoztatta tárgyalási pozícióját és stratégiáját a globális és a regionális gazdasági tér- 
ben egyaránt. India bő négy évtizeden át (a függetlenség 1948-as elnyerésétől az 1990-es évek elejéig) meglehetősen bezárkózó gazdaságpolitikát folytatott, $s$ ennek megfelelően igen kevéssé volt aktív a nemzetközi (akár multilaterális, akár regionális) gazdasági tárgyalásokon. Kereskedelmi rendszerének 1991-ben megindított kiterjedt liberalizációja nyomán az ország nemzetközi tevékenysége, aktivitása is fokozódott. India elsősorban a WTO fórumain hallatta markánsan a hangját, s a 2000-es évek legelejére a fejlődő országok egyik fö szószólójává vált a nemzetközi kereskedelempolitikai fórumokon. Jellemző példája volt ennek a 2006-os „gyapot-megállapodás", amikor a fejlődő országok India vezetésével rávették az USA-t, hogy 40 év után végre alkalmazza a legkevésbé fejlett országoknak nyújtandó vámmentesség elvét a 4 szegény afrikai országból származó gyapotimportra. ${ }^{20} 2013$ decemberében, a WTO Baliban tartott 9. Miniszteri Értekezletén az utolsó utáni pillanatban ${ }^{21}$ létrejött India-USA megállapodás tette lehetővé a záródokumentum elfogadását, s India ebben az esetben is a fejlödő országok érdekeinek fö képviselőjeként lépett föl.

Mint fentebb jeleztük, India az utóbbi három évtizedben nagyon látványos gazdasági fejlődést valósított meg, s diplomáciai és globális gazdasági tekintélye is folyamatosan erősödött. Mindezek alapján regionális szerepvállalásának erősödése is természetes lenne. Kelet- és Délkelet-Ázsiában nyilvánvalóan egy India - Kína - Japán háromszögben kell kialakulni a regionális erőegyensúlynak. Tekintettel Kína egyre növekvő kereskedelmi fölényére, Japán és India együttesen egyfajta ellensúlyt képezhetne, amely a globális erőegyensúly szempontjából is kiemelten fontos szerepet tölthetne be. India kihátrálása az RCEP-ből nemcsak Japán pozícióit gyöngíti, hanem az egész térség gazdasági-kereskedelmi erőegyensúlyát is destabilizálja. Ha most India végleg hátat fordít a szabadkereskedelmi törekvéseknek, és gazdasága többé vagy kevésbé protekcionista fordulatot vesz, az India fejlődési lehetőségeit korlátozhatja, valamint a térség más államait is tárgyalási pozícióik módosítására ösztönözheti. Szélesebb értelemben India lépése a térség szabad és nyitott gazdasági rendszereinek fejlődését is eltérítheti eddigi útjáról, s megváltoztathatja az ázsiai regionalizmus eddigi trendjét.

Az RCEP-szerződés aláírásának esélyeit némileg rontotta India visszalépése, de nem nyilvánvaló, hogy végleg el is lehetetlenítette. Japán ugyan erőteljesen hangsúlyozza, hogy India nélkül nincs értelme az RCEP-nek, de ugyanezt tette, miután az USA visszavonta aláírását a TPP-ről, majd - átvéve a tárgyalások irányítását - 13 hónappal később aláírta a CP-TPP-t (amit TPP-11nek is nevezhetünk.) Tény azonban, hogy India nélkül az RCEP regionális és globális jelentősége is csökken.

\section{FELhASZnÁlt IRODALOM}

Aggarwal, V. K. (2016): Mega-FTAs and the Trade-Security nexus: The Trans-Pacific Partnership (TPP) and the Regional Comprehensive Economic Partnership (RCEP). Asia-Pacific Issues Analysis from the East-West Trade Center No 123. March. https://scholarspace.manoa. hawaii.edu/handle/10125/40004. Lekérdezve: 2020. 01. 27.

\footnotetext{
${ }^{20}$ Ez volt a WTO Doha-fordulójának egyetlen konkrét eredménye.

${ }^{21}$ Gyakori diplomáciai manővert alkalmazva „megállították az órát”, hogy az még 2013. december 6-át mutasson, amikor a valóságban 7-én 04:30-kor sikerült elfogadni a záródokumentumot.
} 
Chellaney, B. (2019): TRCEP without India isn't Japan's liking. The Japan Times (Opinion). December 17. https://www.japantimes.co.jp/opinion/2019/12/17/ commentary/japancommentary/rcep-without-india-isnt-japans-liking/\#.XjNGeWhKiUk. Lekérdezve: 2019. 12. 21.

Cyrill, M. (2019): Why India has Opted out of the RCEP? India Briefing, November 5. https:// www.india-briefing.com/news/why-india-opts-out-of-rcep-19230.html/. Lekérdezve: 2019. 12. 21.

Fukunaga, Y. (2013): Taking ASEAN+1 towards RCEP. A Mapping Study. ERIA Discussion Paper Series, January. https://pdfs.semanticscholar.org/ 22da/ da08e33333a285f5cf4e24d5301fa2389804.pdf. Lekérdezve: 2020. 01. 27.

Gantz, D. A. (2016): „The TPP and RCEP: Mega-Trade Agreements for the Pacific Rim” Arizona Journal os International \& Comparative Law. 33 (2) https://heinonline.org/ HOL/LandingPage?handle=hein.journals/ajicl33\&div=9\&id=\&page $=. \quad$ Lekérdezve: 2020. 01. 27.Goodman, M. P. (2018): „From TPP to CPTPP” Center for Strategic \& International Studies. March 8. https://www.csis.org/analysis/tpp-cptpp. Lekérdezve: 2018. 03. 10.

Hamada, K. (2015): The Fraught Politics of the TPP. Project Syndicate, október 30. http://www. project-syndicate.org/commentary/tpp-economic-gains-political-obstacles-by-koichihamada-2015-10 Lekérdezve: 2018. 03. 17.

Helble, M. - Xie, Yizhe (Daniel) (2017): Is the CPTPP a risky gamble? East_Asia Forum, December 23. http://www.eastasiaforum.org/2017/12/23/is-the-cptpp-a-risky-gamble/. Lekérdezve: 2018. 03. 12.

(The) Japan Times (2019): Get India back into the RCEP negotiations. November 12. https:// www.japantimes.co.jp/opinion/2019/11/12/editorials/get-india-back-rcep-negotiations/\#. XjNFr2hKiUk. Lekérdezve: 2019. 12. 21.

Koike, Y. (2015): Japan's TPP Transformation. Project Syndicate, Október 30. http://www. project-syndicate.org/commentary/tpp-help-japanese-economic-reforms-by-yurikokoike-2015-10. Lekérdezve: 2018. 03. 17.

Lee, H. - Hakura, K. (2014): „TPP, RCEP, and Japan's Agricultural Policy Reforms” OSIPP Discussion Paper: DP-2014-E-003. March 31. http://www.osipp.osaka-u.ac.jp/archives/ DP/2014/DP2014E003.pdf. Lekérdezve: 2020. 01. 27.

Lewis, M. K. (2015): „TPP and RCEP: Implications of Mega-FTAs for Global Governance” Digital Commons@ University Buffalo School of Law https://digitalcommons.law.buffalo.edu/ articles/649. Lekérdezve: 2020. 01. 29.

Mitra, D. (2019): Why India needs to rethink its decision to opt out of RCEP? The Economic Times, November 15. https://economictimes.indiatimes.com/ news/economy/policy/ why-india-needs-to-rethink-its-decision-to-opt-out-of-rcep/articleshow/ $\quad 72061734 . \mathrm{cms}$. Lekérdezve: 2019. 12. 21.

Oba, M. (2019): The Implications of India's RCEP Withdrawal. Regional trade iniciatives just got more complicated. The Diplomat, November 14. https://thediplomat.com/2019/11/theimplications-of-indias-rcep-withdrawal/. Lekérdezve: 2019.12.21.

Pant, H. V. - Sarma, N. (2019): Modi Was Right. India Isn't ready for Free Trade, Observer Research Foundation, November 20. https://what-is-orf.blogspot.com/2019/11/modi-wasright-india-isnt-ready-for.html. Lekérdezve: 2019. 12. 21. 
Sim, W. (2019): Japan 'not thinking at all' of RCEP deal without India. The Straits Times, november 30. https://www.straitstimes.com/asia/japan-not-thinking-at-all-of-rcep-dealwithout-india. Lekérdezve: 2019. 12. 21.

Vijayakumar, VK (2019): India's RCEP walkout shows its industry is still incompetent. Quartz India, November 21. https:/qz.com/india/1753077/modis-rcep-walkout-shows-indiasincompetence-in-global-trade/. Lekérdezve: 2019. 12. 21.

Wilson, J. D. (2015): Mega-Regional Trade Deals in the Asia-Pacific: Choosing between TPP and RCEP? Journal of Contemporary Asia. 45(2) https://www.tandfonline.com/doi/10.1080/0047 2336.2014.956138. Lekérdezve: 2020. 01. 27.

Ye, Min (2015): China and Competing Cooperation in Asia-Pacific: TPP, RCEP and the New Silk Road. Asian Study, December. https://www.tandfonline.com/doi/abs/10.1080/14799855.201 5.1109509. Lekérdezve: 2020. 01. 27.

Yu, P. K. (2017): The RCEP and Trans-Pacific Intellectual Property Norms. Vanderbilt Journal of Transnational Law https://scholarship.law.tamu.edu/facscholar/1001. Lekérdezve: 2020. 01. 29. 